\title{
АВТОР И ГЕРОЙ КАК ФЕНОМЕНЫ ИСКУССТВА И ДЕЙСТВИТЕЛЬНОСТИ
}

\author{
Е.К. Соболевская
}

Я не герой своей жизни. М. Бахтин

При изучении произведения искусства или художественной реальности мы, как правило, не обходимся без категорий автора и героя. В зависимости от определенной эпохи могут меняться их облик, объем, актуализироваться те или иные частные моменты, но, в общем, мы попрежнему именуем автором того, кто создает произведение, а героем того, кто действует (или иногда бездействует) в рамках художественной реальности.

Возможно ли опыт, извлеченный из художественной сферы, применить к сфере действительной жизни, которая вот сейчас осуществляется и к которой каждый из нас непосредственно причастен? Возможно ли аналогичным образом структурировать действительность и говорить о ней, используя тот же терминологический аппарат? Если, по Бахтину, «я не герой своей жизни», то могу ли я считаться её автором? Или я могу выступать в качестве автора только по отношению к другому человеку, а тот в свою очередь по отношению ко мне будет выступать в качестве героя? Допуская последнее, попытаемся понять, что это значит занять по отношению к другому позицию автора.

Обратимся к работе М. Бахтина «Автор и герой в эстетической деятельности». Вот что он говорит, когда мыслит категории автора и героя применительно к сфере искусства (в данном случае - к литературе):

Актуальні проблеми духовності 
Общая формула основного эстетически продуктивного отношения автора к герою: отношения напряженной вненаходимости автора всем моментам героя, пространственной, временной, ценностной и смысловой вненаходимости, позволяющей собрать в с ег о героя, который изнутри себя самого рассеян и разбросан в заданном мире познания и открытом событии этического поступка, собрать его и его жизнь и восполнить до целого теми моментами, которые ему самому в нем самом недоступны, както: полнотой внешнего образа, наружностью, фоном за его спиной, его отношением к событию смерти и абсолютного будущего и пр., и оправдать и завершить его помимо смысла, достижений, результата и успеха его собственной, направленной вперед жизни. ${ }^{1}$

А вот что говорит Бахтин позднее, когда категории автора и героя уже выведены им за сферу искусства:

Эстетический подход к внутреннему бытию другого требует прежде всего, чтобы мы не верили и не надеялись на него, а ценностно принимали его помимо веры и надежды, чтобы мы были не с ним и не в нем, а вне его ... Память начинает действовать, как сила собирающая и завершающая, с первого же момента явления героя, он рождается в этой памяти (смерти), процесс оформления - есть процесс поминовения.

И далее, что особенно важно для нас:

Смерть, как смысловая неудача и неоправданность, подводит смысловой итог и ставит задачу и дает методы несмыслового эстетического оправдания. ${ }^{2}$

По сути дела, подход Бахтина к данным категориям остается неизменным. И в одном, и в другом случае Бахтин настойчиво говорит о так называемом «несмысловом эстетическом оправдании» автором своего героя, но с очевидностью нигде не раскрывает смысл этого процесса (если это вообще «процесс») применительно к сфере жизни.

${ }^{1}$ Бахтин $М$. Автор и герой в эстетической деятельности // Собр. соч.: В 7 т. T. 1. - M., 2003.-C. 96 .

${ }^{2}$ Там же.-C. 200. 
Я могу понять, что значит восполнить литературного героя до целого теми моментами, которые ему самому принципиально трансгредиентны (полнотой внешнего образа, наружностью, фоном за его спиной и т. д.); я могу понять, что восполнение героя не только путь автора, но и путь читателя (второго автора). Более того, я понимаю, что как для автора, так и для читателя, жизнь героя должна завершиться там, где завершается само произведение. Даже если герой не умирает, он всё равно в смысле должен быть мертв для нас. Мы не можем навязывать ему за-текстовую жизнь ни в её этическом, ни в её познавательном движении. Автор и читатель следят и следуют за героем; насколько возможно, предвидят его путь; соучаствуют в его падениях и взлетах и в конце концов «останавливают» его жизнь. Произведение искусства с его непременным условием эстетического завершения героя есть своеобразная форма смерти. Плох герой или хорош, автобиогафичен он или нет, идеализирован он или реалистичен, вовремя он покидает «сцену» или просто уходит в сторону, не совершив главного, мы должны его ценностно принять таким, каким он есть в качестве героя данной художественной реальности. Здесь он представляет ценность сам по себе («Человек здесь вовсе не по хорошу мил, но по милу хорош» $\left.{ }^{3}\right)$. И наши рассуждения «как было бы, если бы...» непродуктивны. Мы должны исходить из того «как есть». В этом, по-видимому, и состоит смысл эстетического завершения героя (или его «несмыслового эстетического оправдания») применительно к сфере искусства.

Но в чем же состоит смысл эстетического завершения героя применительно к сфере жизни?

Я не берусь гадать, что по этому поводу сказал бы Бахтин, как бы он развернул свои положения. Но, может быть, достаточно того, что он высветил для нас событие, из которого мы, будучи потенциальными авторами, должны исходить и в котором мы должны удерживаться, а именно - событие смерти другого близкого нам человека. Здесь наш особый, ни с чем не сравнимый избыток видения. Это место чревато тяжелым, должным вот-вот родиться смыслом, помимо того (или поверх того) смысла, который, с позиций самосознания живущего человека, так и остается незавершенным.

Но будем помнить, избыток видения сохраняется не только за нами. Пока мы находимся в состоянии горя или раздавленности эмпи-

\footnotetext{
${ }^{3}$ Такой формулой определял Бахтин специфику эстетического видения в более раннем тексте.-См.: Бахтин M. К философии поступка // Собр.соч... Т. 1.M., 2003.-C. 57 .
} 
рическим событием смерти, пока еще взор наш замутнен неведением и непониманием бытия, в избытке в идения по отношению к нашему личному умершему уже-всегда находится Другой. В Другом и через Другого смысловая незавершенность жизни завершается во всех её возможных планах. Жизнь завершается в целом, судится и милуется. Именно Тому единственному Другому жизнь человека изначально предстает со всеми её вариантами и одновременно в её эйдетической завершенности. Он предвидит множество путей, но любуется одним: единственной и единичной жизнью и, сращенной с ней, единственно возможной смертью. Именно Он знает, состоялась ли наша душа в мире, сбылась ли она так, как была задумана, или мы прожили не свою жизнь и, соответственно, приняли не свою смерть.

Смерть, по глубинному постижению Р.-М. Рильке, прорастает из недр каждой отдельной жизни, она присутствует в её лоне, в её чреве. Мы вынашиваем и взращиваем её (каждый именно свою единственную и единичную), как мать вынашивает и взращивает свое дитя. Но, в отличие от матери, мы не видим результатов собственного труда. Наши роды непременно заканчиваются смертью, полной и окончательной на биологическом уровне, и смертью как некой трансценденцией, вынесенной за пределы нашего земного сушествования (на уровне метафизическом), и, тем не менее, сращенной с ним. И мы можем лишь надеяться, что вскормленный нами плод предстанет Богу и миру немертворожденным. Только Другой, обладая совершенным ведением и в идением, безошибочно знает, насколько это материнское дело всей нашей жизни удается. Ни на самого человека, ни на того, кто позднее становится его автором, сие дело не возложено. Отсюда и невозможность суда над другим, героем, отсюда и неправомерность мысли «как было бы, если бы он не умер», и отсюда же - единственно возможное - принять случившееся как имеющее смысл и эстетически оправдать своего героя. Оправдывая другого (героя), мы одновременно оправдываем и Другого (Автора), оправдываем Его волеизъявление, Его допущение, чтобы случившиеся в бытии события предстали в такой-то час, в таком-то месте, в такой-то форме.

Покоящийся в бытии эйдос жизни другого отбрасывает свет, кажет себя. И мы, при всем своем несовершенстве, способны этот отблеск непосредственно наглядно созерцать. Доверие Божественному замыслу (Другому) и умные очи - вот всё, что необходимо. И тогда над эмпирическим событием смерти, бессмысленным и страшным, надстраивается некий ино-предмет, ино-событие - иное со-бытие - судьба нашего героя. Мы удерживаем эту предметность актами сознания. В ней в ка- 
честве ядра эйдос жизни другого уже содержится. Он обладает полнотой смысла. Будучи трансцендентным по своей природе и открываясь в рамках нашего имманентного сознания, он, тем не менее, содержанием данного сознания не является. И, поскольку эйдос жизни $\partial p y$ -

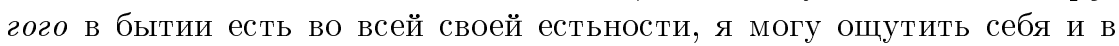
качестве автора своих близких, личных умерших, и-вопреки времени и пространству - в качестве автора давно ушедших «неблизких» и «неличных» умерших. Как это не покажется самонадеянным, но для меня может заново умереть Сократ, Рильке, Цветаева.. . И только я, со своего единственного в бытии места, могу выстроить (высвободить) судьбу каждого из них так, как она мне в своем смысле и бытии дается. Судьба не будет выглядеть здесь как «слепой рок», как темное иррациональное начало бытия (ведь не из жизни в смерть лежит наш путь), но будет выглядеть как зрячее Божественное провидение и проведение, поскольку через смерть мы будем проецировать жизнь (и н ожизнь).

Пытаясь объять жизнь наших умерших, а по сути дела, выстроить её заново, мы исходим из факта той определенной смерти, какая перед нашим взором обнажена, хотим мы того или нет. В этой своей смерти герой однолик и односмертен. Одноликой становится и его жизнь, земная жизнь. Она безнадежно завершена и сокрыта от нашего взора. Она уже предопределена и обусловлена светом своей единственной и единичной кончины. У автора (другого) один непререкаемый путь: от уже известного настоящего - в ставшее единственно возможным прошлое, или - путь от будущего к настоящему, где настоящее уже будущим предопределено и не является просто ожидаемым положением вещей. Онтологически данные границы жизни героя формируют потенциальную возможность необратимо «вывернутой» точки зрения автора. И здесь Бахтин абсолютно прав: в смысле герой «должен быть мертв для нас, формально мертв». Только применительно к сфере жизни я бы сказала: герой должен быть мертв для нас в буквальном и единственно возможном смысле. Смерть должна выполнить свою работу и тем самым обозначить конец жизни. Смерть должна тяготить нас окончательной завершенностью жизни. Но только тогда смерть, будучи гарантированной и полной, сможет послужить для нас в качестве формы эстетического видения и только тогда герой станет однозначно мертв для нас, когда мы займем устойчивую позицию вне веры и надежды нашего героя. Нет такой позиции - нет ни автора, ни героя.

В свое время, размышляя о смерти Скрябина, Осип Мандельштам писал: 
Я хочу говорить о смерти Скрябина как о высшем акте его творчества. Мне кажется, смерть художника не следует выключать из цепи его творческих достижений, а рассматривать как последнее, заключительное звено. С этой вполне христианской точки зрения смерть Скрябина удивительна. Она не только замечательна как сказочный посмертный рост художника в глазах массы, но и служит как бы источником этого творчества, его телеологической причиной. Если сорвать покров времени с этой творческой жизни, она будет свободно вытекать из своей причины-смерти, располагаясь вокруг нее, как вокруг своего солнца, и поглощая его свет. ${ }^{4}$

Очевидно, что Мандельштам занимает здесь действительно особую позицию. Это видение уже не отсюда, а из какого-то подвешенного состояния. У Мандельштама «повернуты» глаза души. Смерть как эмпирическое событие просто-напросто редуцируется, и зоркий глаз поэта усматривает иное положение вещей. Оказывается, смерть художника вовсе не конец творческого пути, как это обычно полагают, а последнее, итоговое, с наивысшей полнотой реализованное произведение. Именно из него произрастают и к нему тянутся все достижения его творческой жизни. Без этого плодоносного семени (умирающего и родящего) художника просто нет.

Учитывая определенный контекст и своего рода единичность, особость кончины Скрябина, увиденной таким образом (или, скажем, кончины Пушкина, о которой Мандельштам также вспоминает), я все же думаю, что это глубинное прозрение поэта может быть истолковано и в более широком смысле: прежде всего - применительно к художнику как таковому и, кроме того, с некоторыми допущениями - применительно к каждому нашему близкому.

Смерть всегда была спутницей искусства, иногда скрытой, иногда явной. Опыт смерти и опыт истинного искусства крепко-накрепко связаны. Поскольку художник оказывается способным причаститься смерти, постольку он оказывается способным творить. «Быть причастным смерти» для художника означает выход на такой уровень бытия, где он уже не есть некое эмпирическое «я», находящееся в центре им самим по собственному разумению выстроенного порядка вещей, но есть некое безличное «он», растворенное в вещах и образующее в согласии с ними единый строй жизни. Произведение искусства

\footnotetext{
${ }^{4}$ Манделвштам О. Скрябин и христианство // Сочинения: В 2 т. - М., 1990.T. 2.- C. 157
} 
может быть создано только тогда, когда художник сможет истребить в себе греховное корневище самости (попросту говоря, «превзойти самого себя»).

Это та сторона смерти, тот опыт самосознания, который ведом каждому истинному художнику и, как мы знаем, не только художнику, но и философу. Сама философия устами Сократа проговорилась о своем сущностном истоке: «Те, кто подлинно предан философии, заняты на самом деле только одним - умиранием и смертью». Художество в лице Орфея ещё задолго до Сократа знало о невозможности иного пути. И с тех пор сущность его дела не изменилась ${ }^{5}$.

Применительно к художнику как таковому смерть показывает и ту свою сторону, которая полностью вынесена за пределы опыта самосознания. Она открывается не просто другому, а только тому особому другому, который занимает по отношению к умершему необратимо «вывернутую» точку зрения с установкой на эстетическое оправдание. Именно эта специфическая позиция характерна для Мандельштама. Он усматривает в смерти Скрябина «соборную русскую кончину» и сквозь нее впервые созерцает судьбу художника. Перед нами иной Скрябин, заново родившийся через смерть в жизнь («смертью смерть поправ»).

K сожалению, мы располагаем неполным текстом размышлений Мандельштама. Это всего лишь отрывки выступления, которые сложно использовать в качестве развернутого примера. Но и в имеющемся тексте очевидно просматривается основное устремление автора оправдать творческий путь Скрябина через посредство его кончины. И это очень важно для нас.

Как замечает Мандельштам, Скрябин разорвал с «голосом», увлекся «сиреной пианизма» и тем самым «оторвался от христианской музыки, пошел своим собственным [путем]...» и всё же явил своей смертью пример «соборной русской кончины». Она-то и пролила «ослепительный и неожиданный свет» на его творчество. И вот как оно в итоге нашему автору явлено:

Скрябин - следующая после Пушкина ступень русского эллинства, дальнейшее закономерное раскрытие эллинистической природы русского духа. Огромная ценность Скрябина для России и для христианства обусловлена тем, что он безумствующий

\footnotetext{
${ }^{5}$ Поскольку здесь данный аспект смерти не является предметом нашего непосредственного внимания, отсылаем читателя к обстоятельному исследованию: Бланшо М. Пространство литературы.-М., 2003.
} 
эллин. Через него Эллада породнилась с русскими раскольниками, сожигавшими себя в гробах. ${ }^{6}$

Помещая кончину Скрябина в центр его творческой жизни, Мандельштам усматривает законнорожденность и красоту этой жизни, зрячими перстами слова он осязает радостное со-бытие с её необратимой исполненностью в смысле, в Логосе. Душа Скрябина в мире сбылась, состоялась, и мир состоялся и сбылся в ней.

Но в чем же особость кончины Скрябина? Чем обусловлена позиция Мандельштама, показывающая данную кончину именно в таком ракурсе? Или это всего лишь навязанный извне образ, призрак, порожденный больным воображением поэта?

Известно, что в последние годы жизни Скрябин, находясь под воздействием идеи соборного искусства, работал над воплощением такой сверхжанровой формы, как Мистерия, но внезапная смерть, последовавшая из-за внешне нелепой причины ${ }^{7}$, прервала реализацию этого замысла. Мистерия как действо, выходящее за рамки искусства, как действо религиозного порядка и событие мирового масштаба, знаменующее обновление человечества, было остановлено смертью. В данном контексте смерть обрела мистический смысл. Это не извне налетевшая губящая сила, всё сметающая и всё обессмысливающая, это - необходимая ступень, часть Мистерии, за которой следует соборование народа и его действительное обновление, обновление через посредство жертвенной смерти художника. Единение в смерти. Смерть Скрябина стала телом задуманной им Мистерии.

Таким образом была воспринята кончина Скрябина лучшими представителями русской культуры начала века. Целостный образ судьбы художника был укоренен в бытии духом соучаствующих в этой соборной кончине, духом творивших эту кончину, как таковую не имевшую места в эмпирической действительности. И Мандельштам явился выразителем уже пульсирующего в бытии образа. Он-некий о́рган видения собора, соборный автор.

Подобную позицию по отношению к Скрябину занимал и Вячеслав Иванов. Без преувеличения можно сказать, что вынашиваемая Скрябиным Мистерия была их общим детищем. Кто, как ни Иванов, знал и свято помнил исконное назначение художника - быть религиозным устроителем жизни, теургом, истолкователем и укрепителем божественной связи сущего; и кто, как ни он, мог стать полноценным

\footnotetext{
${ }^{6}$ Манделъитам О. Указ. соч. - С. 158.

${ }^{7}$ Осложнение фурункула губы, за которым последовало заражение крови.
} 
соавтором и соучастником уже чреватого словом ${ }^{8}$ соборного действа?! Для него Скрябин был действительно личным, глубоко интимным умершим. И если для кого-то смерть Скрябина могла предстать в качестве обычного исхода болезни тела, где, кстати говоря, мог иметь место и благополучный финал, то Иванов, скорее всего, предчувствовал и пред-узнавал эту болезнь как свидетельство уже неминуемой жертвенной смерти художника, которая является необходимым истоком задуманного им мистериального действа. Нигде в своих текстах, посвященных Скрябину, Иванов не говорит о его кончине как о факте эмпирической действительности, но везде - как о явлении символического порядка. Он не выносит эту смерть за пределы творческой жизни художника. Она для него - сердцевина жизни. Её живительные токи питают и впервые со всей очевидностью высвечивают творческий путь умершего - путь подвижнический. Более того, будучи символистом в глубинном, истинном смысле слова, Иванов принимает смерть Скрябина не только как имеющую отношение к творческой жизни самого художника или как имеющую отношение к его собственной творческой жизни, но - как ярко выраженную плоть таинства, которому причастны все через эту смерть соборующиеся. Она для него одновременно и сердцевина всенародной жизни, древний символ, произрастающий из самых глубин бытия и возводящий (причащающий) созерцающих его к этим глубинам. Подтверждение тому - величественное поминальное слово (статьи, речи, стихотворения $)^{9}$.

Яркий пример особой авторской позиции (в принятом нами смысле) очевиден и в текстах М.Цветаевой. Её творческое наследие, как, может быть, ни одно другое, дает все основания говорить, что эта позиция была ею вполне осознана и отрефлектирована. Стоило только где-то случиться смерти, Цветаева тут же погружалась в стихию слова, дабы осмыслить состоявшуюся жизнь. Смерть Райнера Рилькеодно из самых выпуклых звеньев в её поминальном ряду.

Как известно, Цветаева узнает о кончине Рильке 31-го декабря накануне Нового 1927 года. Тогда она и обращается к нему с последним, одиннадцатым, уже посмертным письмом; затем следует «Новогоднее» и позднее - «Твоя смерть», произведения, адресованные также непосредственно Рильке.

\footnotetext{
${ }^{8}$ Работа над поэтическим текстом «Предварительного Действия» была начата Скрябиным в 1913 году. После его смерти, в 1919 году, данный текст был опубликован («Русские пропилеи» - Т. VI. - 1919.).

${ }^{9}$ См.: Мылъникова И.А. Статьи Вячеслава Иванова о Скрябине // Памятники культуры: Новые открытия: Ежегодник, 1983.-Л., 1985.
} 
Для цветаевского сознания, настроенного в высшей степени символически ${ }^{10}$, было необходимо увидеть в смерти Рильке прообраз смерти-искупления, смерти-жертвы. Рильке должен был умереть какой-то особой смертью, ни с чем не сравнимой. Но когда Цветаева обращается к ближайшим обстоятельствам смерти поэта, эмпирика ставит её в тупик. Две вещи, очень важные для неё- дата смерти Рильке и причина его смерти - оказываются бессмысленными: поэт умер не в свой день и не в свой год, да к тому же ещё от «испорченной» крови. Так, после получения известия о кончине Рильке, Цветаева пишет Пастернаку: «Он умер 30-го декабря, а не 31-го ${ }^{11}$. Еще один жизненный промах. Последняя мелкая мстительность жизни - поэту» ${ }^{12}$.

Но это было бы не по-цветаевски оставить за такой датой пустоту. Ей нужна была некая чувственно осязаемая красота данного часа, его единственность, необратимость, которая сокрыта от нас привычным, но бессмысленным потоком времени. И немного позднее, перекрыв эмпирику, Цветаева усматривает в этом часе онтологический час высшего порядка с его исполненностью в смысле - Рождество Христово. В эмпирически данный час Рильке умирает, но на другом срезе бытия он рождается в новую жизнь. И усмотреть этот чаемый смысл Цветаевой удается через текст, что, в частности, подтверждают строки из «Новогоднего», отсылающие нас к событию Рождества:

$$
<\ldots>\quad \text { (соломой }
$$

Застелив седьмой - двадцать шестому

Отходящему - какое счастье

Тобой кончиться, тобой начаться!)

И ближе к финалу:

В небе лестница, по ней с Дарами... ${ }^{13}$

\footnotetext{
${ }^{10}$ Напомню читателю очень показательное в этом плане высказывание Цветаевой: «Для поэта самый страшный, самый злостный (и самый почетный!) врагвидимое. Враг, которого он одолеет только путём познания. Поработить видимое для служения незримому - вот жизнь поэта. $<\ldots>$ Поэт есть тот, кто должен знать всё до точности. Он, который уже всё знает? Другое знает. Зная незримое, не знает видимого, а видимое ему неустанно нужно для символов. „Alles Vergängliche ist nur Gleichniss"» (См.: Собр.соч.: В 7 т. - Т.5.- М., 1995.- С.284). - Строка из «Фауста» Гёте, которая, как правило, переводится так: «Всё преходящее есть только подобие».

${ }^{11}$ На самом деле Р.-М. Рильке умер 29-го декабря, но тогда Цветаева об этом ещё не знала.

${ }^{12}$ Цветаева М. Собраний сочинений: В 7 т. - Т. 6. - М.,1995. - С. 266.

${ }^{13}$ Там же.- Т. 3. - С. 134, 136. - В поминальных стихах, посвящённых Блоку,
} 
Подобным образом Цветаева поступает и с причиной смерти Рильке - «Blutzersetzung» (разложение крови), как она её именует по-немецки. Казалось бы, что тут можно усмотреть, кроме очередной иронии жизни (быта)?! Но не тут-то было. Причина смерти Рильке расценивается Цветаевой как явление символического порядка, в форме которого возвещает о себе нечто существенно большее - Жизнь поэта в её целостном смысле.

Знаю, - обращается Цветаева к Рильке,-что медицинская болезнь, от которой ты умер, лечится переливанием крови, то есть близкое лищо, хотящее спасти, отдает свою. Тогда болезнь кончается. Твоя болезнь - началась с переливания крови - твоей - во всех нас. Больным был мир, близким лицом его-ты. Что тогда спасёт перелившего!

Поэзия ни при чём. «Только лишняя порча крови», «что зря кровь портить», - так говорит быт. Предел этого «зря» и «лишнего»- окончательная порча крови, то есть смерть. Твоя смерть $^{14}$.

В данном случае Цветаева видит смерть Рильке в качестве единичного, законнорожденного события, замены которому нет. «Blutzersetzung»- никак иначе «германский Орфей» умереть не мог. Такая смерть - не просто закономерное следствие творческой жизни Рильке, но - причина и исток этой жизни. Именно такая жизнь, сращенная именно с такой смертью, своей смертъю, нужна была больному миру, и она в мире состоялась, воплотилась во всей полноте. Мир спасен жертвенной смертью поэта.

Так видеть может только особый автор. Его взгляд «вывернут», необратимо направлен из будущего в настоящее. Это некое будущее, уже имеющее место в настоящем (но не в августиновском смысле - ожидаемого в настоящем будущего, а в смысле будущего, исполнившегося «здесь и теперь»). Причем замечу: перед нами автор, не налагающий свою волю на поверхность вещей, но доверяющий и подчиняющийся тому положению вещей, какое в бытии обозначено свыше. Для самого Рильке, выступающего в качестве героя, эта «вывернутость» по отно-

Цветаева также основывается на дате Рождества Христова и таким образом восходит от мотива погребения к мотиву рождения своего героя («Стихи к Блоку» (II) и цикл «Вифлеем»).- См. подробнее: Соболевская E. «Стихи к Блоку» (II) M. Цветаевой как поминальный жанр // Константин Бальмонт, Марина Цветаева и литературные искания ХХ века.-Иваново, 1998. - Вып. 3.

${ }^{14}$ там же. - T. 5. - C. 204. 
шению к себе невозможна, его взгляд необратимо направлен от настоящего (с учетом прошлого) к ещё не свершившемуся будущему, к бесконечному горизонту равновозможных вариантов одного и того же финального события - смерти. Кстати говоря, по беглому замечанию М.Бланшо, Рильке «категорически отказывался узнавать, от чего он умирал...» ${ }^{15}$. Почему? - Это другой вопрос, и я не берусь делать далеко идущие выводы. Важно, что знание «от чего» ему не требовалось, оно уже не могло стать его делом. Оно должно было стать делом $\partial p y$ 20го.

Еще один пример особой авторской позиции представлен в статье В. Соловьева «Судьба Пушкина».

Автор этой работы откровенно сознается, что поначалу роковая смерть Пушкина в расцвете его творческих сил казалась ему «вопиющею неправдою, нестерпимою обидою» и что «действовавший здесь рок не вязался с представлением о доброй силе». Он же был всегда уверен в возможности и даже необходимости объяснять роковые события $c$ истинной точки зрения, или $c$ точки зрения божественного провидения. Невозможность это сделать в случае с Пушкиным тяготила философа. Но позднее, когда стали известны новые обстоятельства кончины поэта, Соловьев пришел к «печальному утешению»: Пушкин окончил свой земной путь «сообразно своей собственной воле»; «Пушкин убит не пулею Геккерна, а своим собственным выстрелом в Геккерна» ${ }^{16}$.

Разлад между этической и эстетической сферами, между действительностью жизни (выстрел как установка на свершение нравственного зла) и действительностью, открывавшейся творческому гению в минуты вдохновения (через красоту поэт восходит к добру и истине), должен был быть разрешен. И он мог быть разрешен не обязательно посредством дуэли, а посредством усилия воли подняться на доступную для Пушкина высоту, «где неуязвимость гения сливалась с незлобием христианина». Но этот шаг с его стороны сделан не был. И Соловьев, превозмогая обычное, механическое в $u$ дение кончины поэта и сохраняя по отношению к нему чувство глубокой любви, утверждает своевременность и нравственную необходимость данной смерти. Не губящей силой предстает здесь смерть, а единственным спасением.

Как убедительно показывает автор, дальнейшая жизнь Пушкина, в случае противоположного исхода дуэли, обернулась бы для него ка-

\footnotetext{
${ }^{15}$ См.: Бланио М. Указ. соч.- С. 125.

${ }^{16}$ См.: Соловъев В.С. Стихотворения. Эстетика. Литературная критика.-М., 1990. - C. 345,360 .
} 
тастрофой. Трехдневные физические страдания, приведшие его к духовному возрождению, были бы заменены «многолетней нравственной агонией», которая убила бы в нем поэта. Совершив сознательное убийство человека, он не смог бы по-прежнему приносить священную жертву поэзии.

Смерть художника - событие особого порядка. Тем не менее, художник - не единственная персона в бытии, делающая позицию автора продуктивной. Смерть философа - тоже почва благодатная. Пример тому - диалог Платона «Федон».

Буквально с самого начала смерть Сократа погружается в символический контекст и сращивается с жизнью философа. В сущности, перед нами одно событие, замкнутое на самое себя, и, кажется, что весь диалог создан именно ради него. «Те, кто подлинно предан философии, заняты на самом деле только одним - умиранием и смертью» и «Критон, мы должны Асклепию петуха. Так отдайте же, не забудьте»- вот А и $\Omega$ этого события, его материнское лоно и плод. «Я всю жизнь умирал, ибо иначе жизнь в свете философии невозможна, и теперь, пройдя через врата смерти, я заново обрету жизнь», - так мог бы сказать Сократ. Жизнь и смерть меняются местами: жил умирая, умирая живу. Одна указывает на другую. Мы перестаем понимать, когда на самом деле Сократ живет, а когда - умирает, то ли смертьисток жизни, то ли жизнь - исток смерти. Платон делает все, чтобы мы окончательно запутались и сменили угол зрения, «вывернули» очи души. И нет ничего удивительного в том, что слова Сократа ставят в тупик его учеников. И коль скоро мы занимаем их позицию, а они здесь представительствуют за обыденное, эмпирическое сознание, разрывающее целостное событие жизни-смерти на жизнь и на смерть, на причину и следствие, мы действительно ничего не поймем и, конечно же, не рассчитаемся с Асклепием. Но если нам удастся сменить угол зрения и занять авторскую позицию, то мы увидим смерть Сократа не в качестве следствия жизни, но в качестве её телеологической причины. Из неё, как из символа, зерна, вся жизнь Сократа проистекает, произрастает, и к ней же устремляется, преобразуясь в колос. Именно через такую, поистине сократовскую, единственную и единичную смерть Платон выводит своего героя в жизнь.

В отличие от смерти художника и философа, смерть обычного человека кажется не столь говорящей и явно лишенной смысла. И, в общем, понятно почему. В отношении к художнику и к философу задача автора, можно сказать, наполовину решена: смерть уже завершила (оформила) и втянула в свой смысловой контекст родственные ей 
события жизни героя, сам способ его бытия, его творчество как упражнение в смерти. Целостное событие его смерти-жизни уже чуть ли не телесно дано. И автору остается приложить лишь некоторое усилие, чтобы соединить очевидно явленные, но эмпирически разрозненные звенья. По сути дела, смерть художника - это уже прорастающее автором семя. В отношении же к человеку, чей способ бытия далек от так называемого упражнения в смерти, задача автора усложняется. Здесь просто нет готовых звеньев, которые можно было бы соединять. Перед нами в большинстве случаев хаотический поток жизни и ничего не говорящая смерть. И автору, таким образом, нужно в этом сплошном потоке разглядеть нечто, что помогло бы ему своего рода обычную смерть обустроить в качестве смерти единичной и необычной, в качестве смерти выношенной, выстраданной и вместе с тем гармонически предустановленной самим Божьим промыслом. Для автора его личный умерший, герой, не может быть «обычным». Если есть «обычность», «ничего особенного» или сплошная раздавленность эмпирикой смерти, значит, нет автора, соответственно, - нет и героя. Коль скоро мы беремся за нелегкое дело эстетически оправдать и завершить земной путь наших близких, не Губительницей должна видеться смерть, ноРодительницей, осеняющей своими крылами отошедшего. И, как это не покажется странным, после первого естественного удара смерти настоящий автор должен испытать некую удовлетворенность, просветленность, успокоенность, другими словами - катарсис. Думаю, что каждый из нас хотя бы раз в жизни по отношению к своим близким, «обычным» умершим, испытывал нечто подобное. Но надо иметь в виду, что так называемый катарсис возможен только в том исключительном случае, если мы занимаем доверительную позицию по отношению к бытию и его Автору, Другому, позицию, в основании которой лежит любовь не в субъективно-психологическом, а в объективнометафизическом смысле. Это позиция милующая, благоволящая, благо-желающая, благо-склоняющаяся. Здесь все зависит от внутренних способностей автора, его терпеливого и напряженного всматривания в происходящие события. Любая деталь, ранее не значимая, теперь может оказаться значимой и говорящей. Автору не на кого положиться. Смерть и жизнь героя в его руках.

В качестве примера вспомним, как осмысливается кончина в общем обычного человека в произведении Рильке «Записки Мальте Лауридса Бригге»:

То не была смерть кого-то, больного водянкой; то была же- 
стокая княжья смерть, которую камергер в себе питал и вынашивал. Всеми излишками гордости, своеволия, властолюбия, которые он не растратил в спокойные дни, теперь завладела смерть, и смерть, окопавшись в Ульсгоре, их расточала.

Как взглянул бы камергер Бригге на того, кто пожелал бы ему умереть не такой смертью, иначе? Он умер своей, тяжкой смертью. $^{17}$

Для лирического героя Рильке, который в данном случае рассуждает с позиций автора (в принятом нами смысле), самым существенным оказывается то, что его герой умирает не от болезни. Ведь определенная болезнь несет всем, заболевшим ею, одну и ту же смерть, один и тот же летальный исход, готовый, обезличенный. А здесь поверх просто-смерти (от какой-либо болезни) надстраивается еще одна смерть, личная, становящаяся готовой не сама по себе, но за счет усилий определенной единичной и единственной в своем роде жизни. В этом и состоит красота и одновременно смысл данной смерти. И в $и$ дение смерти как исполнившегося в красоте смысла, а не просто смерти как больного тела, разбитого водянкой, - заслуга автора, сумевшего над эмпирикой смерти подняться и в эстетическом плане «завершить» своего героя.

Для Рильке, так много размышлявшего о смерти, всегда был важен неразличимый для обыденного сознания момент-сращенности смерти с жизнью. Жизнь лишь тогда предстает в полном виде, когда смерть помещается в её лоно. Они взаимодополняют друг друга. Вспомним хотя бы такие строки из «Часослова»:

O Herr, gieb jedem seinen eignen Tod.

Das Sterben, das aus jenem Leben geht, darin er Liebe hatte, Sinn und Not.

Denn wir sind nur die Schale und das Blatt.

Der große Tod, den jeder in sich hat, das ist die Frucht, um die sich alles dreht. ${ }^{18}$

\footnotetext{
${ }^{17}$ Pильке P.-М. Записки Мальте Лауридса Бригге: Роман.-СПб., 2000. - С. 15.

${ }^{18}$ Рилъке P.-М. Стихотворения: Сб.- М., 1998.- С. 55. - В пер. В. Куприянова эти строки звучат так:

Своею смертью пусть любой умрет

На склоне жизни, что была полна

Любви и страсти, смысла и невзгод.

Мы только оболочка, мы листва,

И смерть внутри любого существа,

Как плод всего, чем плоть увлечена.
} 
Заметим, что смерть (der Tod), не без оснований именуемая здесь плодом (die Frucht), сразу же дает два смысла: «плод» в смысле начала жизни и «плод» в смысле конечного её результата. Der Tod (= die Frucht) - центр всего происходящего, вокруг него заверчена вся жизнь. Кроме того, в первой строфе «der Tod» через рифму сближается со словом «die Not»- нужда, необходимость, а значит, отливает и его светом. И, как видим, Рильке утверждает здесь возможность такой особой смерти для всего сущего без исключения. Она в таком своем виде, пусть не очевидно, но природно, бытийственно задана. Дело живущих состоит в том, чтобы природную заданность воплотить.

Обозначенная позиция поэта пересекается с той позицией, которая названа нами позицией автора по отношению к действительной жизни. По сути дела, во всех приведенных выше примерах авторского в $и$ дения ведущим является один и тот же мотив-смерть как плод жизни, и одновременно-жизнь как плод смерти. И это не просто в $и$ дение, дарованное каждому зрящему кончину своего умершего. Это действительно избыток видения (в наиболее полном значении), особая ступень и особая степень, и чтобы там оказаться нужно суметь отстраниться от привычного эмпирически данного положения вещей. Нужно отстраниться от отношения смерти другого к себе самому, от того, что собственно для меня из неё следует. Прекрасная Дама без пощады не терпит сентиментальных слез и вздохов. За этими естественными, механическими движениями чувств не разглядеть её истинного лика. Она открывается только спокойному, отстраненному от эмпирики взору. С моментом отстранения разрывается текучая ткань времени и наступает момент единственного и единичного по своей сути «здесь и теперь» - момент кайроса: когда в определенный, единственно заданный момент времени те же вещи воспринимаются в своем собственном «странном» виде. У истинного автора «вывернут» орган восприятия мира. И то, что даровано созерцать ему, никогда не может быть воспринято (созерцаемо) с позиций эмпирической действительности. Какой внутренней силой отстранения должна была обладать Ахматова, чтобы на второй день после кончины Пастернака ${ }^{19}$ принять его смерть как исток жизни:

Умолк вчера неповторимый голос,

И нас покинул собеседник рощ.

Он превратился в жизнь дающий колос

${ }^{19}$ И это притом, что сама она находилась в больнице после очередного инфаркта. 
Или в тончайший, им воспетый дождь. ${ }^{20}$

Для того, чтобы подвести итог такой особой точке зрения и окончательно уяснить позицию автора, а соответственно, структуру созерцаемого им пространства деятельности героя, восстановим в памяти небольшой отрывок из произведения Павла Флоренского «Иконостас», где описываются различные формы в идения мира - глазами «дольними» и глазами «горними»:

То же самое явление, которое воспринимается отсюда из области действительного пространства - как действительное, оттуда - из области мнимого пространства - само зрится мнимым, т. е., прежде всего, протекающим в телеологическом времени, как цель, как предмет стремлений. И напротив, то, что есть цель при созерцании о тс юда и, по нашей недооценке целей, представляется нам хотя и заветным, но лишенным энергии, - и деалом, - оттуда же, при другом созерцании, постигается как живая энергия, формующая действительность, как творческая форма жизни. Таково вообще внутреннее время органической жизни, направленное в своем течении от следствия к своим причинам-целям. ${ }^{21}$

K данному заключению Флоренский пришел в результате размышления о феномене сна, который, будучи точкой соприкосновения двух миров (эмпирического, «дольнего», и ноуменального, «горнего»), является живым свидетелем иной действительности и, соответственно, - иного взгляда. Если речь идет о сновидении вечернем, знаменующем переход из эмпирического пространства в пространство ноуменальное, то созерцаемая нами действительность - лишь пустое подобие повседневной жизни с её механическими, внутренне не обусловленными, но привычными для нашего восприятия связями (между событиями). Такие сновидения, как правило, не задерживаются в нашей памяти и восстановлению практически не подлежат. Другое дело, когда речь идет о сновидении предутреннем, знаменующем переход обратный - из ноуменального пространства в пространство эмпирическое. Когда наш внутренний взор очищен от эмпирики и наполнен опытом пребывания в ноуменальном, созерцаемая нами действительность представляет полную противоположность действитель-

\footnotetext{
${ }^{20}$ Ахматова А. Сочинения: В 2 т. - Т. 1. - М., 1990. - С. 252.

${ }^{21}$ Флоренский П. Иконостас // Сочинения: В 4 т. - Т. 2. - М., 1996. - С. 426. Заметим, что в терминологии Флоренского «мнимое пространство» и есть пространство подлинно реальное, или подлинно действительное.
} 
ности повседневной жизни. Именно она-то, несмотря на её «остраненность», и запоминается надолго, ибо события, её организующие, внутренне обуславливают друг друга. Время здесь бежит с бесконечной быстротою «н а в с т р е ч у настоящему, п р о т и в движения времени бодрственного сознания. Оно в ы в рн у то через себя и, значит, вместе с ним вывернуты и все его конкретные образы». Причина здесь появляется не прежде своего следствия (следствий), а «после всех них, завершая весь ряд и определяя его не как причина действующая, а как причина конечная, $\tau \varepsilon \lambda о \varsigma »^{22}$.

Аналогичная картина вырисовывается и в связи с феноменом смерти в его отношении к жизни. С позиции «дольнего», неавторского взгляда, смерть представляется лишенным смысла следствием жизни. «Дольний» взгляд упрямо зрит горизонталь и располагает события в том порядке, который привычен для повседневной действительности и который не может обусловить их внутренней смысловой необходимости. С этой точки зрения мы никогда не получим героя. «Горний» же взор, авторский, устремлен поперек привычного горизонтального видения. Он разрывает, или редуцирует, «горизонталь», и событие смерти предстает перед ним именно как феномен, сквозь который высвечивается ноуменальное положение вещей. И тогда смерть-не следствие жизни, но - её конечная причина, её телос. Автор созерцает героя в его целостности как отзвук подлинно сущей круглости бытия.

Увидеть эмпирическое событие смерти глазами «горними», пребыть в этом событии и означает эстетически завершить жизнь наших умерших помимо её собственной смысловой незавершенности.

${ }^{22} \mathrm{Cм} .:$ Там же. 